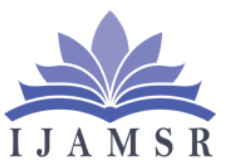

International Journal of Advanced Multidisciplinary Scientific Research (IJAMSR) ISSN:2581-4281

\title{
Impact of Organisational Climate on Effectiveness in Teaching of Secondary School Teachers
}

\author{
Sajad Hussain Kawa \\ Research Scholar, Dept. of. Education, Glocal University, Saharanpur, U.P., India
}

Email:Sh453170@gmail.com

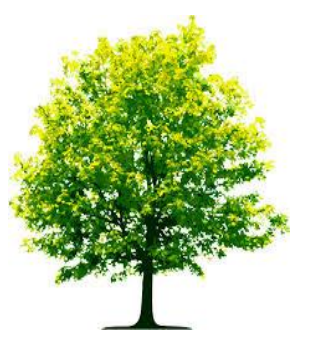

Keywords:

Organisational Climate,

effective and less effective secondary school teachers in Kashmir valley.

\begin{abstract}
A B S T R A C T
This study examined the Attitude towards Teaching of effective and less effective secondary school teachers in Kashmir valley. The sample of the study consisted of 800 secondary school teachers which were collected by random sampling. Attitude towards teaching scale developed by using S.P. Alullwalia's was used. The results of the study revealed that the effective secondary school teachers have a favorable attitude towards teaching as compare moderate secondary school teachers. The results also revealed that effective teachers are more competent in their jobs and also show a positive attitude and are more cooperative to the students and heads of institutions.
\end{abstract}

Citation: Sajad Hussain Kawa (2019). Impact of Organisational Climate on Effectiveness in Teaching of Secondary School Teachers. International Journal of Advanced Multidisciplinary Scientific Research (IJAMSR) ISSN:2581-4281, 2 (1), January, 2019, \# Art.1121, pp 72-78

\section{Introduction}

Education in the largest sense is an act or an experience that has a formative effect on the mind, character or physical ability of an individual. In its technical sense, education is the process by which society deliberately transmits its accumulated knowledge, skills and values from one generation to another society. Education in real sense is to humanize humanity and to make life progressive cultured and civilized. It is very important for the progress of the individual and society. It is through 45education that man develops his thinking and reasoning, problem solving, intelligence and creativity and aptitude, positive sentiments and skills, good values and attitudes. Education is a dialogue between the past, present and the future, so that the coming generations receive the accumulated lessons of the heritage and carry it forward (UNESCO, 1998). 


\section{International Journal of Advanced Multidisciplinary Scientific Research (IJAMSR) ISSN:2581-4281}

Attitude means the individual's prevailing tendency to respond favorably or unfavorably to an object, person or group of people, institutions or events. Attitude can be positive (values) or negative (prejudice). The attitude has been defined in many different ways over the years. The attitude of the teacher has an impact on the behavior of the student in the classroom as well. The teacher spends most of the school day in the close association with his students and as a result of this; his basic attitudes and actions, his tastes and mannerism have great influence on the students. The teachers create the emotional climate in the classroom just by being friendly calm or nervous. This directly affects the children because children learn attitudes and behavior mostly by example. The effectiveness of education depends upon the quality of teachers working in an institution. The quality of teachers in turn depends upon the quality of training received by them in different training institutions. The teacher spends most of the school day in close associations with his students and as a result of this, his basic attitudes and actions, his tastes and mannerism have great influence on the students, the teacher creates the emotional climate in the classroom just by being friendly, calm and nervous. This directly affects the children because children learn attitudes and behavior mostly by examples, emotion, tension, For example, is contagious; a teacher who is fear full and generally hostile can induce fear, worry, and insecurity in his students. The effectiveness of teacher, mainly depends upon the character, ability and his attitude towards his profession teaching. It is true that the attitude of a person towards his profession plays an important role in achieving desirable success. The attitude of a person depends upon his emotions and feelings. Renu and Nand, ( 1999) conducted a study on the attitude of effective teachers towards the teaching profession. The main findings of her study were the effective teachers possess better teaching skills than less effective teachers. Their academic scores are high. They are more cooperative with students (Panday, R and Tripathy, 2006) conducted a study on the attitude of efficient school teachers. The findings indicate that there are good results of education by effective teachers. They have direct influence on the personality of students. The effectiveness of education depends upon quality teachers working in institutions. The quality of teachers in turn depends upon the quality of training received by them in different training institutions. As we know that qualitative and quantitative improvements of elementary and secondary educations has raised problems of solutions of right type of teachers and enriching program of teacher preparation. Thus necessities, but also to inculcate in them desirable teacher like qualities. We know the teaching profession is one of the most important art of guiding students through a variety of methodologies selected teaching methods, and it should therefore, attract the brightest minds, finest personality and most commitment young people as a profession, it requires people who have the right type of attitude for teaching is bound to be a successful teacher in future. 


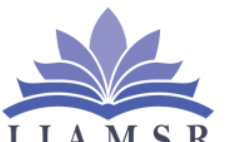

\section{International Journal of} Advanced Multidisciplinary Scientific Research (IJAMSR) ISSN:2581-4281

\section{Statement of the problem}

The quality of classroom teaching in the school depends upon the quality of education of teachers and quality of education of teachers depends upon the good organizational climate and effectiveness in teaching etc. Quality education is the cry of the modern age. So teacher education is a very important issue in the education system.

The present study purports to investigate the teacher effectiveness in relation to organizational environments. The present research endeavor is conducted to fulfill the gap in the role of organizational climate in teacher effectiveness among teachers. We anticipate that there is a practical advantage in studying these variations collectively as it will lead to an intervention program for teachers.

\section{Organizational Climate}

For a long time, the term "climate" has been rather generally and imprecisely used to describe the "feeling" or "atmosphere" or "tone" of the organization. The term "organizational climate" has been given somewhat precise meaning in recent years through the contributions of a number of researches. Organizational Climate is a term that was probably first used by Cornell in 1955. He used the term to denote a "delicate blending of interpretations or perceptions of persons in the organization, of their jobs or roles in relationship to others, and their interpretation of the roles of others in the organization".

\section{Organizational Climate in Education}

Hatpin says that "Anyone who visits more than a few school notes quickly how schools differ from each other I their „feele ${ }^{\text {ee }}$ In the school the teachers and the principal are zestful and exude confident in what they are doing. They find pleasure in working with each other; this pleasure is transmitted to the students, who thus are given at least a fighting chance to discover that school can be a happy experience. In a second school the brooding discontent of teacher is palpable; the principal tries to hide his incompetence and his lack of a sense of direction behind a clock of authority, and yet he wears his clock poorly because the attitude he displays to others vacillates randomly between the obsequious and the officious. And the psychological sickness of such a faculty spills over to the students who, in their own frustration, feedback to the teachers a mood of despair. A third school is marked by neither joy nor despair, but by hollow ritual. Here one gets the feeling of watching an elaborate charade in which teachers, principal and students alike are acting out parts. The acting is smooth, even glib, but it appears to have little meaning for the participants, in a strange way the show just does not seem to be for real. And so, too, as one move to other schools, one finds that each appears to have a "personality" of its own. It is this "Personality" that we describe as the "organizational climate" of the school. Analogously, personality is to the individual what organizational climate is to the organization". 


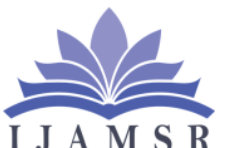

\section{International Journal of} Advanced Multidisciplinary Scientific Research (IJAMSR) ISSN:2581-4281

\section{Teacher's effectiveness}

The concept of teacher effectiveness is defined as the way of measuring great success of teacher in finishing up institutional along with other specific obligations required via the quality of his/her position of employment Teacher effectiveness comprise usefulness in techniques of teaching, student and classroom management, inter individual connections, analysis and response etc. The teacher effectiveness consists of two acquainted words 'teacher' and 'effectiveness'. Teacher is basically an individual who educates i.e. convey information or capabilities towards the learner. 'Effectiveness' happens to be the high quality of being successful in coming up with a planned result' (Collin's English Dictionary).

Teaching effectiveness is vital due to the fact that useful instructing helps pupil learning. It has become even more important as the emphasis on quality in higher education has grown. Highly effective educating doesn't happen inadvertently. Effective teachers have grown to be great at what they do due to the fact they examine their training. James (n/d) implies that "educational evaluation is a high quality, accountability for educational staff, developing coming from a commitment to grasping ramification educating on pupils and to improve student learning." There are various methods of assessing teaching or checking its effectiveness. Beck (2005) recognizes "twelve possible forms of clue of teaching effectiveness." Some of these are:
- Student rankings

- Peer reviews

- Self-reviews

- Video clips of practice

- Conversations with student

- Alumni, employer and manager ratings

- Educating prizes and scholarship

- Learning end result measures

\section{Significance of the Study}

The present research study is required by the deficiency of research on the role of organizational climate and teacher effectiveness in teachers in Indian context. Therefore, it is expected that the outcomes of this research would subsidize to the body of knowledge on the role of organizational climate and teacher effectiveness in teachers. The study may also provide a basis for future researchers to test its findings as well as the various possible hypotheses arising from it. This will help to build and strengthen the body of knowledge on the relevance of organizational climate and teacher effectiveness in teachers. In addition, the study outcomes would provide administrators, policy makers as well as those charged with the responsibility of implementing policies on students, with empirical evidence on the importance of organizational climate and teacher effectiveness for the teachers. 


\section{International Journal of} Advanced Multidisciplinary Scientific Research (IJAMSR) ISSN:2581-4281

\section{Studies in India}

Some attempts had been made by the Indian research scholars to study the Organizational Climate of the schools. Some of the significant studies had been reviewed below.

Sharma, M. L. (1971) carried out "An Investigation into Organizational Climate of Secondary Schools of Rajasthan." He investigated into the organizational climate of 30 tribal secondary schools of the Churn district in Rajasthan and established that open climate of the schools will help in getting higher achievement of the students in comparison to closed climate. He used the organizational climate description questionnaire (OCDQ) tool and collected the marks secured by students at the Board Examination to study differences in academic performance of the students of the schools in different climatic condition. He observes that schools having an open and autonomous climate were found to have a significant high achievement index as compared with those of closed climate. He concluded that open and autonomous climates enhance high achievement while the close climate affects students ${ }^{\text {ee }}$ achievement adversely. He further found that the correlation coefficient of different dimensions of OCDQ with an achievement which were disengaged - 0.67 , spirit - 0.59, hindrance -0.33 , intimacy -0.25 , aloofness -0.46 , production emphasis -0.21 , thrust -0.58 and consideration -0.44 .

\section{Studies Related to Organizational Climate and Effectiveness in Teaching}

Gandhi, K.A. (1977) conducted a study on "Personality characteristics of teaching staff and organizational climate of schools of Haryana". The major objectives of the study were (i) to classify the schools on a climatic basis, (ii) to study the factors that contribute most to the creation of climates, (iii) to determine the extent to which the belief systems of teachers in open climate school differ from those of teachers of the closed climate. The findings were: significant differences were found to exist between open intermediate and 83 closed climate schools: teachers serving in relatively open school were significantly more humanistic in their pupil control ideology than their counterparts. The belief system of urban and rural teachers in open and closed climate differed significantly.

Homelike, H.L. (1980) found out "The relationship between teacher's belief systems and perceptions of organizational climate in high and low change-oriented elementary schools". In this study there was a significant relationship between school organizational climate and Teacher effectiveness of urban male and female teachers. Teacher's belief and perceptions of organizational climate in high and low change oriented elementary schools. It was concluded that teachers were not academically prepared to deal with personal philosophy about educational theory and practices nor human relations and collaborative decision making processes. 
Bangalore". He found autonomous climate, private management, unaided schools and urban location of schools to be the most conducive factors in the development of social maturity. Further, the controlled climate, government management and urban locality were found to be conducive to the development of morale of teachers. No single dimension of organizational climate was found to be effective for the development of social maturity of students.

\section{Objectives of the Study}

The researcher had considered the following objectives which were found important to carry out the study.

a) To measure the organizational climate of the secondary educational institutions.

b) To measure the teacher effectiveness in teaching at the secondary educational institutions.

c) To find out the relationship, if any, among organizational climate and teacher effectiveness in teaching at the secondary educational institutions.

d) To study the influence of organizational climate on teacher effectiveness of secondary school teachers of Kashmir valley.

\section{Statement of Hypotheses}

For the present study the following hypotheses were framed
H1: There would be a significant difference in School Organizational Climate between-

a) Male and female teachers,

b) Urban male and rural male teachers,

c) Urban female and rural female teachers,

d) Urban male and urban female teachers,

e) Rural male and rural female teachers,

$\mathrm{H} 2$ : There would be a significant difference in Effectiveness in Teaching between

a) Male and female teachers,

b) Urban male and rural male teachers,

c) Urban female and rural female teachers,

d) Urban male and urban female teachers,

e) Rural male and rural female teachers,

H3: There would be a significant relationship in School Organizational Climate and Effectiveness in Teaching between entire sample. 


\section{Methodology:}

Methodology can properly refer to the theoretical analysis of the methods appropriate to a field of study or to the body of methods and principals particular to a branch of knowledge. In the present study the Descriptive Survey method will be used. The sample of the study will consist of 400 High School Teaches selected randomly, out of which 200 teachers will be from Government Schools and 200 from Private Schools. In order to obtain the desired result from this study, the tools that will be used are: School Organizational Climate Descriptive Questionnaire (SOCDQ) developed and standardized by Motile Sharma.

In the present study School Organizational Climate Descriptive Questionnaire developed by Motile Sharma (1973) consisted of 64 items based on 8 different dimensions. In all there are 64 Likert type items distributed over eight dimensions (sub-test). The respondents are asked to indicate the extent to which each statement characterizes his/her school. The scale against which the respondents indicate the extent to which each statement characterizes their school is defined by four categories: (1) Rarely Occurs, (2) Sometimes Occurs, (3) Often Occurs and (4) Very Frequently Occurs. For scoring these four categories of responses there are assigned four successive integers viz. 1, 2, 3, 4 respectively. Then for each respondent, eight sub-test scores are calculated by simple summation of each respondents item score, subtest by subtest and dividing each of the eight sums by the number of items in the corresponding subtest.

\section{Teacher Effectiveness Scale (TES):}

Teacher Effectiveness Scale (TES) developed and standardized by Pramod Kumar and D. N. Mutha.

In the teacher effectiveness scale all the 69 items are positively worded. Items are given a score of '5', '4', '3', '2', and '1' for 'totally agree', 'agree', 'uncertain', 'disagree' and 'totally disagree' respectively. The sum of these values gives the teacher-effectiveness score for the subject. The total score varies from the 69 to 345 . Different statically techniques will be used to analyze the data.

\section{References}

1. Arogundade, B.B., and E.O. Olorunsola. 2012. "Organizational climate and lecturers job performance in South West Nigeria Universities." Journal of Educational and Social Research 2(1): 51-57. doi: 10.5901/jesr.2012.02.01.51

2. Babu, V. R. M., and A. V. R. Reddy. (1996. Organizational climate of schools in relation to type of school and sex of teachers." Perspectives in Education 12: 159-168.

3. Garg, P., and R. Rastogi. 2006. "Climate profile and OCBs of teachers in public and private schools of India." International Journal of Educational Management 20: 529 - 541. doi: 10.1108/09513540610704636.

4. Hameed, A., and M. Manjusha. 2010. "Teacher efficacy of Secondary school teachers in relation to teaching styles and organizational culture." Edusearch 1: 64-70. 